\title{
Tetrahydrobiopterin metabolism in the temporal lobe of patients dying with senile dementia of Alzheimer type
}

\author{
PA BARFORD, JA BLAIR, C EGGAR, C HAMON, C MORAR, SB WHITBURN \\ From the Department of Chemistry, The University of Aston in Birmingham, Birmingham UK
}

SUMMARY There is a defect in tetrahydrobiopterin metabolism in brains from subjects with senile dementia of Alzheimer type compared to age-matched controls. This defect results in lowered total biopterin concentrations in brain. Brains from subjects with senile dementia of Alzheimer type retain their ability to synthesis neopterin and have normal dihydropteridine reductase activity, indicating a specific loss of ability to convert dihydroneopterin triphosphate to tetrahydrobiopterin.

The synthesis of dopamine and noradrenaline in the brain is dependent upon the activity of tyrosine hydroxylase, and this in turn is regulated by the concentration of the hydroxylase cofactor, $5,6,7$, 8-tetrahydrobiopterin $\left(\mathrm{BH}_{4}\right) .^{1}$ Recent reports have suggested a defect in $\mathrm{BH}_{4}$ metabolism in senile dementia of Alzheimer type; biopterin concentrations in serum ${ }^{2}$ and $\mathrm{CSF}^{3}$ are lowered in patients with senile dementia of Alzheimer type compared to age-matched controls, suggesting a role for $\mathrm{BH}_{4}$ in the pathology of senile dementia of Alzheimer type. Williams $\mathrm{et} \mathrm{al}^{4}$ have shown that biopterin concentrations in CSF fall with age, suggesting a decrease in the tetrahydrobiopterin available for neurotransmitter biosynthesis. We have studied $\mathrm{BH}_{4}$ synthesis, dihydropteridine reductase activity and biopterin and neopterin concentrations in the temporal lobe of patients dying with senile dementia of Alzheimer type and in age-matched controls, and report the results here.

\section{Method}

\section{Brain samples}

Samples of temporal lobe (Brodmann area 20) removed at necropsy from eight normal subjects and eight subjects

Address for reprint requests: Prof JA Blair, Dept of Chemistry, University of Aston in Birmingham, Birmingham B4 7ET, UK.

Received 7 July 1983 and in revised form 17 January 1984. Accepted 30 January 1984 with senile dementia of Alzheimer type were obtained from the MRC brain bank. These brain samples were matched for age, drug therapy and time to necropsy. Brain samples were stored at $-70^{\circ} \mathrm{C}$ until required. Twenty per cent homogenates of brain samples in $0 \cdot 1 \mathrm{M}$ tris buffer $\mathrm{pH}$ 7.6 were prepared and centrifuged at $100000 \mathrm{~g}$ for 40 minutes. Supernatants were used for all measurements. Protein was measured by the biuret method. Each brain sample was assayed for dihydropteridine reductase, $\mathrm{BH}_{4}$ synthesis activity, total neopterin and total biopterin.

\section{Assay of dihydropteridine reductase}

Dihydropteridine reductase was assayed by the method of Craine et al. ${ }^{5}$ Each incubation contained $10^{-4} \mathrm{M}$ nicotinamide adenine dinucleitide, reduced form (NADH) $10^{-3} \mathrm{M} \mathrm{H}_{2} \mathrm{O}_{2}, 8 \mu \mathrm{g}$ horseradish peroxidase, 2.5 $\times 10^{-4} \mathrm{M}$ sodium azide, $10^{-4} \mathrm{M}$ 6, 7-dimethyltetrahydropterin, in $0.05 \mathrm{M}$ tris buffer $\mathrm{pH} 7.6$, and $0.02 \mathrm{ml}$ of brain extract in a total volume of $1 \mathrm{ml}$.

\section{Measurement of $\mathrm{BH}_{4}$ synthesis}

$\mathrm{BH}_{4}$ synthesis was measured by the method of Fukushima et al. ${ }^{\circ}$ Each incubation contained $6 \times 10^{-3} \mathrm{M}$ guarmosive triphosphate (GTP), $3 \times 10^{-3} \mathrm{M}$ adenine dinucleitide phosphate, reduced form (NADPH), $10^{-3} \mathrm{M} \mathrm{MgCl}_{2}$ and $0.1 \mathrm{ml}$ of brain extract in $7.5 \times 10^{-4} \mathrm{M}$ tris buffer $\mathrm{pH} 8.0$, in a total volume of $1 \mathrm{ml}$. Under these conditions the synthesis was linear for a period of $3 \mathrm{~h}$ and the concentrations of NADPH and GTP were not rate limiting. For controls incubations were carried out in the absence of GTP and/or NADPH. Incubation was for $3 \mathrm{~h}$ at $37^{\circ} \mathrm{C}$ in the dark. The reaction was stopped with $2 \mathrm{ml}$ of $0 \cdot 1 \mathrm{M} \mathrm{HCl}$ and reduced biopterins oxidised with $\mathrm{I}_{2}{ }^{7}$ Total biopterin 
was measured by (HPLC) high performance liquid chromatography.

Measurement of total neopterin and total biopterin concentrations in brain homogenates was by HPLC after acidiodine oxidation.?

\section{Results and discussion}

Recovery of $\mathrm{BH}_{4}$ synthesising activity and dihydropteridine reductase from control brain and senile dementia of Alzheimer type brains was 90-95\% showing that, as in the rat, ${ }^{6} \mathrm{BH}_{4}$ synthesising enzymes and dihydropteridine reductase are in the cell supernatant fraction.

Kinetic measurements on the synthesis of $\mathrm{BH}_{4}$ in control brains showed that the concentrations of GTP and NADPH used for the incubation were not rate-limiting. Because senile dementia of Alzheimer type brains showed little or no synthesis of $\mathrm{BH}_{4}$, it was not possible to carry out kinetic measurements on these samples. Determination of $\mathrm{Km}$ for dihydropteridine reductase in control brain extracts and senile dementia of Alzheimer type brain extracts gave $\mathrm{Kms}$ of $1.2 \times 10^{-5} \mathrm{M}$ and $1.5 \times 10^{-4} \mathrm{M}$ for 6,7 , dimethyltetrahydropterin and NADH respectively. These values are similar to those for the sheep liver enzyme ${ }^{5}$. There was no correlation between time to necropsy and either $\mathrm{BH}_{4}$ synthesis activity or dihydropteridine reductase in either group.

$\mathrm{BH}_{4}$ metabolism was impaired in the brains of subjects with senile dementia of Alzheimer type compared to age-matched controls (table). Synthesis of $\mathrm{BH}_{4}$ was significantly lower in senile dementia of Alzheimer type brains $(0.046 \mathrm{ng}$ biopterin $/ \mathrm{mg}$ protein/h) than in the control brains $(0.616 \mathrm{ng}$ biopterin $/ \mathrm{mg}$ protein $/ \mathrm{h})(\mathrm{p}=1 \%$ Wilcoxon sum of ranks). In the control group there was evidence for a decrease in the ability to synthesis $\mathrm{BH}_{4}$ with age, the youngest brain (age 44 years) having a synthesis activity of $1.05 \mathrm{ng}$ biopterin $/ \mathrm{mg}$ protein $/ \mathrm{h}$, six brains aged 70-80 years having a mean of $0.75 \mathrm{ng}$ biopterin/mg protein $/ \mathrm{h}$ and one brain (age 89 years) having synthesis activity of $0 \cdot 11 \mathrm{ng}$ biopterin/mg protein $/ \mathbf{h}$. Dihydropteridine reductase activity in temporal lobes from subjects with senile dementia of Alzheimer type was higher than that in temporal lobes from control subjects, but the elevation was not significant. Measurement of total neopterin and total biopterin in temporal lobes gave a neopterin/ biopterin ratio of 0.55 in control subjects and 5.23 in subjects with senile dementia of Alzheimer type. In temporal lobes from subjects with senile dementia of Alzheimer type the total biopterin concentration had fallen, but the total neopterin concentration had risen compared to age-matched controls.

The results presented here demonstrate a deficit
Table $\mathrm{BH}_{4}$ synthesis, dihydropteridine reductase activity, total neopterin concentration and total biopterin concentration in temporal lobes from subjects with senile dementia of Alzheimer type and age-matched controls. Number of subjects in brackets. Results are expressed as mean \pm standard deviation.

\begin{tabular}{lll}
\hline & $\begin{array}{l}\text { Normal controls } \\
\text { Mean age } \\
71.8 \pm 12.7 \mathrm{yr}\end{array}$ & $\begin{array}{l}\text { Subjects with SDAT } \\
\text { Mean age } \\
77.0 \pm 6.8 \mathrm{yr}\end{array}$ \\
\hline $\begin{array}{l}\text { Synthesis (8) } \\
\text { ng biopterin/mg protein/hr } \mathrm{hr} \\
\begin{array}{l}\text { DHPR (8) } \\
\text { nmol NADH/mg }\end{array}\end{array}$ & $229.4 \pm 11.0$ & $295.5 \pm 143.0$ \\
$\begin{array}{l}\text { protein/min } \\
\text { Total biopterin (7) }\end{array}$ & $0.902 \pm 1.03$ & $0.232 \pm 0.22$ \\
$\begin{array}{l}\text { ng/mg protein } \\
\text { Total neopterin (7) }\end{array}$ & $0.496 \pm 0.35$ & $1.237 \pm 0.94$ \\
$\begin{array}{l}\text { ng/mg protein } \\
\text { neopterin/biopterin ratio }\end{array}$ & 0.55 & 5.33 \\
\hline
\end{tabular}

in $\mathrm{BH}_{4}$ in temporal lobes of subjects with senile dementia of Alzheimer type. This deficit is not due to lack of dihydropteridine reductase, but a failure to synthesise $\mathrm{BH}_{4}$ and is in agreement with the results of Morar et al, ${ }^{3}$ who have shown that total biopterin concentrations were significantly lowered in the CSF of subjects with senile dementia of Alzheimer type compared to age matched controls. $\mathrm{BH}_{4}$ synthesis activity in senile dementia of Alzheimer type brains was $7.5 \%$ of that found in control brains. This decrease was greater than found for other enzymes in senile dementia of Alzheimer type. ${ }^{8}$ The high level of synthesis activity in the one younger subject in the control group compared to older controls is indicative of a decrease in the ability to synthesise $\mathrm{BH}_{4}$ with increasing age, a result which is in agreement with the work of Williams et al, ${ }^{4}$ who have shown that $\mathrm{BH}_{4}$ concentrations in CSF decrease with increasing age. The alteration in the neopterin to biopterin ratio in senile dementia of Alzheimer type compared to controls shows that the failure to synthesise $\mathrm{BH}_{4}$ in senile dementia of Alzheimer type is not due to a defect in GTP cyclohydrolase, the enzyme that converts GTP to dihydroneopterin triphosphate, but that the defect occurs in the biosynthetic pathway after dihydroneopterin and demonstrates a defect in $\mathrm{BH}_{4}$ synthesis in vivo. In this respect the defect is comparable to that found in those neonates who are unable to make $\mathrm{BH}_{4}$ due to a genetic defect.9 These children are able to synthesise dihydroneopterin but lack the ability to convert dihydroneopterin to $\mathrm{BH}_{4}$. Since senile dementia of Alzheimer type brains retain the ability to synthesise dihydroneopterin, but lack the ability to make $\mathrm{BH}_{4}$, and dihydropteridine reductase is unimpaired, it seems unlikely that these results are due to neuronal loss in senile dementia of Alzheimer type brains. 
In conclusion, the temporal lobes from subjects with senile dementia of Alzheimer type had impaired ability to synthesise $\mathrm{BH}_{4}$ compared to age-matched controls. The defect in $\mathrm{BH}_{4}$ synthesis was not due to loss of brain cells, but to a loss of ability to convert dihydroneopterin to $\mathrm{BH}_{4}$. The results suggest that the capacity to synthesise $\mathrm{BH}_{4}$ decrease with increasing age, and that loss of the capacity to synthesis $\mathrm{BH}_{4}$ may contribute to the development of Alzheimer's disease.

The authors are grateful to Dr G Reynolds, the Brain Tissue Bank, MRC Neurochemical Pharmacology Unit, Addenbrook's Hospital, Cambridge, for brain samples and to Shell (UK) Ltd for financial support. $\mathrm{CH}$ is the recipient of an SERC studentship.

\section{References}

${ }^{1}$ Lovenberg W, Ames MM, Lerner P. Mechanisms of short term regulation of tyrosine hydroxylase. In: Lipton MA, Dimascio A, Killan KF, eds. Psychopharmacology. A Generation of Progress. New York: Raven Press, 1978:247-59.
${ }^{2}$ Aziz AA, Leeming RJ, Blair JA. Tetrahydrobiopterin metabolism in senile dementia of Alzheimer type. $J$ Neurol Neurosurg Psychiatry 1982;46:410-3

${ }^{3}$ Morar C, Whitburn SB, Blair JA, Leeming RJ, Wilcock GK. Tetrahydrobiopterin metabolism in senile dementia of Alzheimer type. J Neurol Neurosurg Psychiatry 1983;46:582.

${ }^{4}$ Williams A, Ballenger J, Levine R, Lovenberg W, Calne D. Ageing and CSF hydroxylase cofactor. Neurology (Minneap) 1980;30:1233-46.

${ }^{5}$ Craine JE, Hall SE, Kaufman S. The isolation and characterisation of dihydropteridine reductase from sheep liver. J Biol Chem 1972;247:6082-91.

- Fukushima I, Eto I, Mayumi T, Richter W, Goodson S, Shiota T. Biosynthesis of Pterins in Mammalian Systems. Chemistry and Biology of Pteridine. Pfleiderer W, ed. Berlin: De Gruyter, 1975:247-63.

${ }^{7}$ Fukushima T, Nixon JC. Analysis of reduced forms of biopterin in biological tissues and fluids. Anal Biochem 1980;102:176-8.

${ }^{8}$ Rossor MN, Emson PE, Iversen LL, Mountjoy CQ, Roth M, Fahrenkrug J; Rehfeld JF. In: Alzheimer's Disease: A Report of Progress in Research. Corkin S, Davis KL, Growdon JH, Usdin E, Wurtman RJ, eds. New York: Raven Press 1982:15-24.

${ }^{9}$ Leeming RJ, Pheasant AE, Blair JA. The role of tetrahydrobiopterin in neurological disease (Review). $J$ Mental Defic Res 1981;25:231-41. 